\title{
ANALYSES OF DNA FROM ANCIENT BONES OF A PRE-COLUMBIAN CUBAN WOMAN AND A CHILD
}

\author{
Ricardo Lleonart ${ }^{1}$, Eileen Riego ${ }^{1}$, Roberto Rodríguez Suárez ${ }^{2}$, Rafael Travieso Ruiz ${ }^{2}$ and José de la Fuente ${ }^{1}$
}

\begin{abstract}
Molecular anthropology has brought new possibilities into the study of ancient human populations. Amplification of chromosomal short tandem repeat (STR) loci and mitochondrial DNA (mtDNA) has been successfully employed in analyses of ancient bone material. Although several studies have reported on continental Amerindian populations, none have addressed the ancient populations inhabiting the Caribbean islands. We used STR and mtDNA analyses to study the skeletal remains of a Cuban Ciboney female adult holding an infant. Results showed that for the STR analyzed the skeletal remains shared common alleles, suggesting a relationship. Mitochondrial DNA analysis showed sequence identity, thus corroborating a possible mother-child relationship. The mtDNA sequence grouped these remains into haplogroup A, commonly found in Amerindian populations. Based on these results, we speculated on a South American origin of pre-Columbian Antilles populations and possible infanticide practices in these populations. This constitutes the first report on DNA analysis of ancient pre-Columbian Cuban populations.
\end{abstract}

\section{INTRODUCTION}

The study of ancient populations is important for understanding economic, religious and cultural relationships. About 20,000-40,000 years ago, human populations arrived in the American continents through Beringia (Dillehay and Meltzer, 1991; Bonatto and Salzano, 1997). According to recent investigations, between tenth and eight milleniums B.C., the Caribbean Islands, including Cuba and Florida, were inhabited by Arawak populations (Fariñas, 1995). At the end of the 15th century, two groups in different stages of economic and social development were present in Cuba: the "Ciboney" or "Siboney" and the "Tainos" (Bachiller y Morales, 1883; Harrington, 1935; Ortiz, 1935; Tabio and Rey, 1966; La Rosa and Robaina, 1994).

Ancient Ciboney populations existed in Cuba about 4000 years ago. More advanced populations were present in the 10th century, who survived the Spanish conquest until the 18th century (de Herrera, 1729; Harrington, 1935; Ortiz, 1935; Tabio and Rey, 1966; Fariñas, 1995). The main activities of the Ciboney were gathering and fishing, with no agricultural or ceramic work. The social structure of the Ciboney was characterized by "marriage groups" (Fariñas, 1995). It consisted of consanguineous families, which included individuals belonging to the same generation with subsequent exclusion of individuals from different generations, e.g. parents and sons. They lived within their groups with little or no communication with other groups (Fariñas, 1995).
Ciboney burial sites are characterized by a) remains of burial rites with a strong animist influence, $b$ ) the existence of burial sites dedicated exclusively or fundamentally to funerary uses, c) secondary burials, and d) the probable location of offerings near the corpse (Fariñas, 1995). For some specialists, Ciboney burial sites suggest collective burials or even human sacrifice, and class differentiation (La Rosa and Robaina, 1994; Fariñas, 1995). This latter possibility is less likely because of the developmental stage of the Ciboney. However, it could reflect relationships based on maternal affiliation (Rives, 1979). Premature death, epidemics and conflicts between groups cannot be excluded.

DNA analysis has proven to be a powerful tool for forensic and population studies (Holland et al., 1993; Bowcock et al., 1994; Boles et al., 1995). Amplification of chromosomal short tandem repeat (STR) loci and mitochondrial DNA (mtDNA) have been shown to have considerable potential for individual identification (Holland et al., 1993) and have been successfully employed in the analysis of ancient bone material (Hagelberg and Hedges, 1989; Riego et al., 1998). Mitochondrial DNA can also be used to trace maternal inheritance.

The Ciboney burial cave, Marien 2, was discovered near the bay of Mariel (north of Havana Province, Cuba) (La Rosa and Robaina, 1994). Several skeletal remains were found in the cave and we studied the remains of an adult female holding an infant.

\section{MATERIAL AND METHODS}

\section{Skeletal remains and bone specimens}

The skeletal remains analyzed in this study were Biotecnología, P.O. Box 6162, Havana, Cuba. Send correspondence to J.F. Fax: +53-7-336-008/+53-7-218-070. E-mail: jose.delafuente@cigb.edu.cu ${ }^{2}$ Montané Anthropological Museum, Faculty of Biology, University of Havana, Calle 25 el. I y J, Havana, Cuba. found in the cave Marien 2, near Mariel Bay in northern Havana Province, Cuba. This burial site was attributed to 
the Ciboney culture and included 13 adult and 37 infant skeletal remains (La Rosa and Robaina, 1994). Several of the adult remains were found associated with infants ( $\mathrm{La}$ Rosa and Robaina, 1994). One of these couples, an adult 35-39-year-old female (No. 7 in La Rosa and Robaina, 1994) holding a three to four-year-old child (No. 6 in La Rosa and Robaina, 1994), was selected for analysis (Figure 1A). The skeletons, buried in the calcarian soil of the cave, were highly calcified (Riego et al., 1998). Based on radio carbon analysis of charcoal obtained from firesides covering the burial site, the age of these remains was estimated by the Department of Chemistry of the University of Louvain (Belgium) to be around 2,220 \pm 80 years (La Rosa and Robaina, 1994).

\section{DNA extraction}

Large bone fragments were employed for DNA extraction and analysis using the procedure described by Riego et al. (1998). The entire DNA extraction procedure was organized following strict standard rules to avoid PCR contamination. These measures included separated pre- and post-PCR areas, laminar flow cabinets with UV decontamination facilities, separation of operators and equipment for pre- and post-PCR work, and use of aerosol resistant tips and disposable sterile plastic ware among others.

Bone fragments were pulverized with a Universal Mill M-20 (AGEM, Cuba). Five grams of powder was decalcified in 0.5 M EDTA, $\mathrm{pH} 7.5$, three times for $12 \mathrm{~h}$ each and washed twice in sterile distilled water. The remaining pellet was suspended in lysis buffer $(10 \mathrm{mM}$ Tris$\mathrm{HCl}, \mathrm{pH} 8,10 \mathrm{mM}$ EDTA, $100 \mathrm{mM} \mathrm{NaCl}, 2 \%$ SDS, 0.5 $\mathrm{mg} / \mathrm{ml}$ proteinase $\mathrm{K}$ ). After $12 \mathrm{~h}$ at $56^{\circ} \mathrm{C}$ with slow shaking, proteinase $\mathrm{K}$ was added to a final concentration of 1 $\mathrm{mg} / \mathrm{ml}$, and a similar incubation continued for an additional $24 \mathrm{~h}$. The lysate was phenol/chloroform extracted (1:1) once and the aqueous phase was extracted with ether and heated $10 \mathrm{~min}$ at $55^{\circ} \mathrm{C}$ to eliminate organic traces. The remaining DNA solution was concentrated by Centricon 100 (Amicon, USA) to a final volume of 40 to $200 \mu \mathrm{l}$ and washed with sterile distilled water.

A

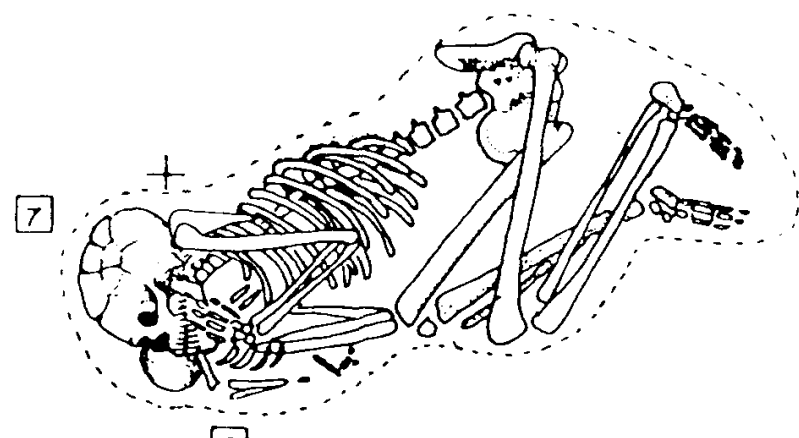

6

B

16194

I

skeletal.....ATGCTTAAAAGCAAGTACAGCAATCAACCTTCAACTATCACACATCAACTGCAACTCCAA

$\star$

16290

I

Anderson.... AGCCACCCCTCACCCACTAGGATACCAACAAACCTACCCACCCTTAACAGTACATAGTA

skeletal.....AGCCACCCCTCACCCACTAGGATACCAACAAACCTATCCATCCTTAACAGTACATAGCA

* * *

16365

I

Anderson.... CATAAAGCCATTTACCGTACATAGCACATTACAGTCAAATCCCTTCTCGTCCC

skeletal..... CATAAAGCCATTTACCGTACATAGCACATTACAGTCAAATCCCTTCTCGTCCC

Figure 1 - A, Skeletal remains belonging to an ancient Cuban pre-Columbian Ciboney adult female (No. 7) holding an infant (No. 6) (La Rosa and Robaina, 1994). B, Sequence of the mtDNA control region compared to the Anderson reference sequence (Anderson et al., 1981) (asterisks denote sequence differences). No differences in this region were found between the skeletal remains. 
Chromosomal short tandem repeat analysis

Several amounts ( 0.001 to $2 \mu \mathrm{l})$ of the extracted DNA were used in PCR reactions containing primer sets to amplify the STR loci HUMCSF1PO, HUMTH01, HUMTPOX, HUMF13A01, HUMFES/FPS, HUMF13B, HUMHPRTB, HUMvWA, HUMLPL and Amelogenin (Robertson et al., 1995; Gill et al., 1995; de Pancorbo et al., 1995). PCR reactions also contained $50 \mathrm{mM} \mathrm{KCl}, 10$ $\mathrm{mM}$ Tris-HCl, $\mathrm{pH}$ 9.0, $1.5 \mathrm{mM} \mathrm{MgCl}, 0.1 \%$ Triton X-100, $0.2 \mathrm{mM}$ each dNTP, $12.5 \mathrm{pmol}$ each oligonucleotide, and 0.5 to 10 units of T. aquaticus DNA polymerase (Heber Biotec S.A., Cuba) in a final volume of $25 \mu$ l. In cases where obvious enzyme inhibition was found, acetylated BSA (New England Biolabs, USA) was included at a final concentration of $170 \mu \mathrm{g} / \mathrm{ml}$. A Minicycler ${ }^{\mathrm{TM}}$ (MJ Research, USA) was employed using Program 3 for the alleles HUMF13B, HUMFES/FPS, HUMHPRTB, HUMLPL and HUMvWA $\left(96^{\circ} \mathrm{C}\right.$ for $2 \mathrm{~min}$, then ten times at $94^{\circ} \mathrm{C}$ for $1 \mathrm{~min}, 60^{\circ} \mathrm{C}$ for 1 min, $70^{\circ} \mathrm{C}$ for $1.5 \mathrm{~min}$, then twenty times at $90^{\circ} \mathrm{C}$ for $1 \mathrm{~min}$, $60^{\circ} \mathrm{C}$ for $1 \mathrm{~min}, 70^{\circ} \mathrm{C}$ for $1.5 \mathrm{~min}$ ). Program 5 was used for Amelogenin, HUMCSF1PO, HUMF13A01, HUMTH01 and HUMTPOX, using the same settings as Program 3 but with an annealing temperature of $64^{\circ} \mathrm{C}$.

After completion of the reaction, $3 \mu \mathrm{l}$ was mixed with the same amount of loading buffer $(10 \mathrm{mM} \mathrm{NaOH}$, $95 \%$ formamide, $0.05 \%$ bromophenol blue, $0.05 \%$ xylene cyanol), heated for $2 \mathrm{~min}$ at $95^{\circ} \mathrm{C}$ and immediately loaded on a denaturing polyacrylamide gel (6\% acrylamide, $7 \mathrm{M}$ urea, $0.5 \mathrm{x}$ Tris borate buffer). Electrophoresis was done at constant power so that gel temperature was $55^{\circ} \mathrm{C}$. After an adequate running time (depending on the marker to be resolved) the gel was silver stained following manufacturer's instructions (Promega, USA). Genotyping for each sample was done by visual comparison of the resulting pattern with allelic ladders containing all the known alleles (Promega, USA).

\section{Mitochondrial DNA analysis}

The same PCR reaction conditions and sets of primers previously described (Wilson et al., 1995) to amplify the control region (HVI) of human mtDNA were used to obtain such regions from the bone-derived DNA. Specifically, primers L16159 (5'-TACTTGACCACCTGTAGTAC$\left.3^{\prime}\right)$ and H16401 (5'-TGATTTCACGGAGGATGGTG-3') (Wilson et al., 1995) were used to amplify a fragment of $242 \mathrm{bp}$. Thermal cycles were $2 \mathrm{~min}$ at $96^{\circ} \mathrm{C}$ followed by 36 times of $1 \mathrm{~min}$ at $94^{\circ} \mathrm{C}, 1 \mathrm{~min}$ at $60^{\circ} \mathrm{C}$ and $1 \mathrm{~min}$ at $72^{\circ} \mathrm{C}$. The product of the correct size was subcloned into the pGEM5ZF T-vector (Promega, USA), and both strands were sequenced on a Vistra 725 Automated sequencer using Texas Red labeled forward and reverse primers (Amersham, UK). Each resulting sequence was compared to the Anderson reference (Anderson et al., 1981), and the differences recorded.

\section{RESULTS AND DISCUSSION}

\section{STR analysis}

The DNA extraction procedure adapted by us rendered amplifiable DNA. However, only for few STR loci it was possible to obtain reproducible results. Furthermore, for the multiplex analysis comprising HUMTH01, HUMTPOX and HUMCSF1PO microsatellites, positive results were obtained only for the two STR with lower amplification sizes. Dilutions up to 1/1000 of the DNA sample were needed to avoid PCR inhibitors. The presence of inhibitors of $T$. aquaticus DNA polymerase has been described and discussed by others (Stoneking, 1995; Cooper, 1997).

The STR analyses showed that the skeletal remains shared common alleles (adult alleles/infant alleles $=6$ and $9 / 6$ and 6 for HUMTH01 and 8 and 12/6 and 8 for HUMTPOX), thus suggesting a possible mother-child relationship.

\section{Mitochondrial DNA analysis}

Amplification of mtDNA sequences is highly sensitive and therefore subjected to false results because of possible contamination. Furthermore, as recently reported (Krings et al., 1997; Lindahl, 1997), ancient bone remains sometimes give unreproducible results because of errors during amplification of damaged DNA. Several extraction-amplification experiments are needed to document the true mtDNA sequence. Experiments and controls were implemented under conditions that reduced possible contamination. Furthermore, extraction-amplification procedures were run in parallel for bone samples of different origin (Riego et al., 1998). The sequences obtained were different, thus emphasizing the absence of contamination in our preparations. Although bone samples were highly calcified, the DNA extraction procedure rendered DNA capable of amplification for STR sequences, therefore reducing the possibility of DNA damage and the risk of false mtDNA sequences. Two clones for each mtDNA were sequenced and no differences were recorded between them.

Analysis of the mtDNA control region has been used to characterize human populations by grouping them according to distinctive haplotypes (Bortolini and Salzano, 1996). We found substitutions in the sequence from the Ciboney skeletal remains analyzed. $\mathrm{T}$ was substituted by $\mathrm{C}$ at positions 16223 and 16290 of the Anderson reference sequence (Anderson et al., 1981) (Figure 1B). These substitutions are characteristic of haplogroup A and are also found in Asia (Bortolini and Salzano, 1996), South American mummies (Monsalve et al., 1996) and abundantly in Boruca (Central America) and Kirahos and Makiritare (South America) populations (Bortolini and Salzano, 1996; Forster et al., 1996).

The peopling of the Antilles has been thought to 
have occurred by Arawakan migrations from the Mato Grosso and Amazonian regions through the Antilles islands (Galich, 1974). Furthermore, previous results have shown that America, and particularly South America, is genetically the most variable region of the world (Bortolini and Salzano, 1996). The fact that the Ciboney analyzed in this study belong to a haplogroup that is highly represented in some South Amerindian populations (Bortolini and Salzano, 1996) does not contradict the hypothesis of South American origin of pre-Columbian Antilles populations.

The sequence of the mtDNA control region was similar for both skeletal remains. Genetic diversity (h) of each population is calculated as $h=\left(1-\mathrm{Sx}^{2}\right) \mathrm{n} /(\mathrm{n}-1)$, where $\mathrm{Sx}^{2}$ is the sum of squares of haplotype frequencies and $\mathrm{n}$ is the sample size. Probability of a random match between two unrelated individuals (Pm) equals $\mathrm{Sx}^{2}$ (Tajima, 1989; Tully et al., 1996). According to mtDNA data, $\mathrm{Pm}=0.054$ and 0.026 for Caucasians and Afro-Caribbeans, respectively (Tully et al., 1996). The data published by Horai et al. (1993) suggests that Pm for African, American and Asian populations equals $0.022,0.051$ and 0.031 , respectively. According to these calculations, Pm for Ciboney populations could be roughly estimated to be between 0.03 and 0.05. On the other hand, Stoneking et al. (1992) estimated that the probability of one mutation in one generation within the mtDNA control region is $3.3 \times 10^{-3}$. Gill et al. (1994) reported the probability of two unrelated individuals differing by just one base to be equal to 0.01 . Considering two possible scenarios: A, mother-child relationship and A', no relationship, the likelihood ratio (LR) for A versus A' was evaluated as follows: a) if sequences are identical, $\mathrm{LR}=\mathrm{A} / \mathrm{A}^{\prime}=1 / 0.04=25 ; \mathrm{b}$ ) if sequences differ by one base, $\mathrm{LR}=3.3 \times 10^{-3} / 0.01=0.33$, and c) if sequences differ by more than one base, $L R=0$. Furthermore, although Ciboney populations must have been genetically highly homogeneous because of their familial organization (Fariñas, 1995), LR for (a) would probably always be higher than 1 , thus corroborating a possible mother-child relationship between the skeletal remains we analyzed.

Considering that finding skeletal remains of adults accompanied by infants is common in Cuba and in other Caribbean islands (Rives, 1979; La Rosa and Robaina, 1994) and that infanticide due to shortage of food, malformations, twin births, diseases or taboos was common in other ancient cultures (Arco and Navarro, 1988), La Rosa and Robaina (1994) proposed infanticide practices in $\mathrm{Cu}$ ban aborigines.

High infant death rates in these groups due to health and other natural problems (Rives, 1979) could explain the association of adult-infant skeletal remains for reasons other than infanticide (Tabio and Rey, 1966); however, the finding of a mother-child relationship would strongly argue in favor of infanticide practices in Ciboney and other pre-Columbian groups. If the mother died from disease, conflict, accident or natural causes, the child could have been sacrificed. This may have been because of the infant's dysfunction, malformation or for economic reasons. Given the familial social structure of Ciboney groups, the rate of dysfunction and malformations was probably high. In fact, a case of infant acromegaly was reported in the archeological site Marien 2 (La Rosa and Robaina, 1994).

\section{ACKNOWLEDGMENTS}

The authors are indebted to Prof. Rivero de la Calle (University of Havana) for helpful discussions and Prof. A. de la Fuente (University of South Florida, Tampa) for critically reading the manuscript.

\section{RESUMO}

A antropologia molecular trouxe novas possibilidades para o estudo de populações humanas antigas. A amplificação de loci em pequenos segmentos cromossômicos repetidos (short tandem repeat, STR) e de DNA mitocondrial (mtDNA) tem sido empregada com sucesso em análises de material ósseo antigo. Embora vários estudos tenham sido publicados a respeito de populações ameríndias continentais, nenhum estudou as populações antigas que habitavam as ilhas do Caribe. Nós usamos análise de STR e mtDNA para estudar os restos de ossos de uma mulher adulta da tribo Ciboney cubana carregando uma criança. Os resultados mostraram que para o STR analisado os restos ósseos compartilhavam alelos comuns, sugerindo um parentesco. A análise de mtDNA mostrou identidade de sequiência, corroborando assim uma possível relação mãe-filho. A seqüência de mtDNA alocou esses restos no haplogrupo $\mathrm{A}$, comumente encontrado em populações ameríndias. Baseado nesses resultados, nós especulamos a respeito de uma origem sul-americana para as populações pré-colombianas das Antilhas e possíveis práticas infanticidas nessas populações. Este constitui o primeiro relato de análise de DNA em populações cubanas pré-colombianas antigas.

\section{REFERENCES}

Anderson, S., Bankier, A.T., Barrell, B.G., de Bruijn, M.H.L., Coulson, A.R., Drouin, J., Eperon, I.C., Nierlich, D.P., Roe, B.A., Sanger, F., Schreier, P.H., Smith, A.J.H., Staden, R. and Young, I.G. (1981). Sequence and organization of the human mitochondrial genome. Nature 290: 457-465.

Arco, M. and Navarro, J.F. (1988). Los Aborigenes. La Biblioteca Canaria, Centro de Cultura Popular Canaria, Spain.

Bachiller y Morales, A. (1883). Cuba Primitiva, Origen, Lenguas, Tradiciones e Historia de los Indios de la Antillas Mayores y las Lucayas. Librería de Miguel Villa, Habana, Cuba, pp. 244-246.

Boles, T.C., Snow, C.C. and Stover, E. (1995). Forensic DNA testing on skeletal remains from mass graves: A pilot project in Guatemala. $J$. Forensic Sci. 40: 349-355.

Bonatto, S.L. and Salzano, F.M. (1997). A single and early migration for the peopling of the Americas supported by mitochondrial DNA sequence data. Proc. Natl. Acad. Sci. USA 94: 1866-1871.

Bortolini, M.C. and Salzano, F.M. (1996). mtDNA diversity analysis in Amerindians and other human populations - how different are they? Braz. J. Genet. 19: 527-534.

Bowcock, A.M., Ruiz-Linares, A., Tomfohrde, J., Minch, E., Kidd, J.R. and Cavalli-Sforza, L.L. (1994). High resolution of human evolutionary trees with polymorphic microsatellites. Nature 368: 455-457. 
Cooper, A. (1997). Reply to stoneking: ancient DNA - how do you really know when you have it? Am. J. Hum. Genet. 60: 1001-1003.

de Herrera, A. (1729). Historia General de los Hechos de los Castellanos en las Islas y Tierra Firme del Mar Oceano. Decada II, Libro II, Cap. VII. Madris, Spain, pp. 33-34.

de Pancorbo, M.M., Castro, A., Alonso, S., Fernández-Fernández, I., Barbero, C., García-Orad, A., Izaguirre, N., Iriondo, M. and de la Rúa, C. (1995). Genetic typing with HUMTH01, HUMVWA31A and HUMFES/FPS short tandem repeat loci, D1S80 variable number tandem repeat and HLA-DQ $\alpha$ from recent and XII-XIII centuries spongy bone. Electrophoresis 16: 1612-1616.

Dillehay, T.D. and Meltzer, D.J. (Eds). (1991). The First Americans: Search and Research. CRC Press, Boca Raton.

Fariñas, D. (1995). La Religion en las Antillas. Academia de Ciencias de Cuba, Havana, Cuba.

Forster, P., Harding, R., Torroni, A. and Bandelt, H.-J. (1996). Origin and evolution of native American mtDNA variation: a reappraisal. Am. J. Hum. Genet. 59: 935-945.

Galich, M. (1974). Nuestros Primeros Padres. Casa de las Americas, Havana, Cuba.

Gill, P., Ivanov, P.L., Kimpton, C., Piercy, R., Benson, N., Tully, G., Evett, I., Hagelberg, E. and Sullivan, K. (1994). Identification of the remains of the Romanov family by DNA analysis. Nat. Genet. 6 : 130-135.

Gill, P., Kimpton, C.P., Urquhart, A., Oldroyd, N., Millican, E.S., Watson, S.K. and Downes, T.J. (1995). Automated short tandem repeat (STR) analysis in forensic casework - a strategy for the future. Electrophoresis 16: 1543-1552.

Hagelberg, E. and Hedges, R. (1989). Ancient bone DNA amplified. Nature 342: 485

Harrington, M.R. (1935). Cuba Before Columbus (Spanish translation). Coleccion de Libros Cubanos, Vol. XXXII. Cultural S.A., Habana, Cuba, pp. 271-290.

Holland, M.M., Fisher, D.L., Mitchell, L.G., Rodríguez, W.C., Canik, J.J., Merril, C.R. and Weedn, V.W. (1993). Mitochondrial DNA sequence analysis of human skeletal remains: identification of remains from the Vietnam war. J. Forensic Sci. 38: 542-553.

Horai, S., Kondo, R., Nakagawa-Hattori, Y., Hayashi, S., Sonoda, S. and Tajima, K. (1993). Peopling of the Americas, founded by four major lineages of mitochondrial DNA. Mol. Biol. Evol. 10: 23-47.

Krings, M., Stone, A., Schmitz, R.W., Krainitzki, H., Stoneking, M. and
Paabo, S. (1997). Neanderthal DNA sequences and the origin of modern humans. Cell 90: 19-30.

La Rosa, G. and Robaina, R. (1994). Infanticidio y Costumbres Funerarias en los Aborigenes Cubanos. Multigraf, Havana, Cuba.

Lindahl, T. (1997). Facts and artifacts of ancient DNA. Cell 90: 1-3.

Monsalve, M.V., Cardenas, F., Guhl, F., Delaney, A.D. and Devine, D.V. (1996). Phylogenetic analysis of mtDNA lineages in South American mummies. Ann. Hum. Genet. 60: 293-303.

Ortiz, F. (1935). Historia de la Arqueologia Indocubana. Coleccion de Libros Cubanos, Vol. XXXIII. Cultural S.A., Habana, Cuba, pp. 228-234.

Riego, E., Lleonart, R., Saínz de la Peña, M.V., Amaro, F., Bacallao, K., Santiesteban, M., Rolo, F., Herrera, L., Blanco, M. and de la Fuente, J. (1998). Purification of DNA from ancient human bone remains for gene typing analysis. Biotecnol. Aplicada 15: 25-29.

Rives, A. (1979). Acerca de la discutible existencia de sacrificios humanos entre los recolectores indocubanos. Bol. Soc. Venez. Espeleol. 7: 4776.

Robertson, J.M., Sgueglia, J.B., Badger, C.A., Juston, A.C. and Ballantyne, J. (1995). Forensic applications of a rapid, sensitive, and precise multiplex analysis of the four short tandem repeat loci HUMVWF13/A, HUMTH01, HUMF13A01, and HUMFES/FPS Electrophoresis 16: 1568-1576.

Stoneking, M. (1995). Ancient DNA: how do you know you have it and what can you do with it? Am. J. Hum. Genet. 57: 1259-1262.

Stoneking, M., Sherry, S.T., Redd, A.J. and Vigilant, L. (1992). New approaches to dating suggest a recent age for the human mtDNA ancestor. Philos. Trans. R. Soc. Lond. Biol. Sci. 337: 167-175.

Tabio, E. and Rey, E. (1966). Prehistoria de Cuba. Academia de Ciencias de Cuba, Havana, Cuba.

Tajima, F. (1989). Statistical method for testing the neutral mutation hypothesis by DNA polymorphism. Genetics 123: 585-595.

Tully, G., Sullivan, K.M., Nixon, P., Stones, R.E. and Gill, P. (1996). Rapid detection of mitochondrial sequence polymorphisms using multiplex solid-phase fluorescent minisequencing. Genomics 34: 107113.

Wilson, M.R., Polanskey, D., Butler, J., DiZinno, J.A., Replogle, J. and Budowle, B. (1995). Extraction, PCR amplification and sequencing of mitochondrial DNA from human hair shafts. Biotechniques 18: 662-669.

(Received March 5, 1998) 
